\title{
MEMBACA LIRIK LAGU POPULER INDONESIA: PERKEMBANGAN TEKNOLOGI KOMUNIKASI DAN BAHASA
}

\author{
READ INDONESIAN POPULAR SONG'S LYRICS: \\ THE DEVELOPMENT OF COMMUNICATION \\ TECHNOLOGY AND LANGUAGE
}

\author{
Galuh Bayuardi \\ Antropologi Universitas Tanjungpura Pontianak \\ Jln. Hadari Nawawi, Pontianak \\ zegavon@gmail.com \\ Dian Equanti \\ Pendidikan Geografi IKIP PGRI Pontianak \\ Jln. Ampera No. 88, Pontianak \\ deaquanti@gmail.com
}

Diterima tanggal 30 Agustus 2018

Disetujui tanggal 27 Desember 2018

\begin{abstract}
Popular song lyrics are products of popular culture that convey messages and ideas from their creators to listeners. This study aims to describe the development of communication technology and language recorded in popular song lyrics. The procedure of the research carried out included the selection and confirmation phase of the chosen songs, reading the text to find vocabulary related to the use of communication technology and language, then conducting intertextual analysis of the text of different songs to observe the intertextual relationship of song lyrics. The results of this study showed that the development of communication technology could be investigated through the lyrics of popular Indonesian songs from amateur radio, cable telephone, radio, pagers, cellular phones with text messages (Short Messaging Service), internet networks and social media. Language development as an implication of the use of communication technology appears in the special language in communication in form of technical terms, codes, expression, and new vocabularies. The intertextuality of numbers of popular song lyrics explain there is similarity of situation, that is introductory process and love relation which built through the use of communication tool and media, also feel that resulted from the voice nuisance of communication tools.
\end{abstract}

Keywords: song, technology, communication, and language. 


\section{ABSTRAK}

Lirik lagu populer merupakan produk budaya populer yang dapat menyampaikan pesan dan gagasan dari penciptanya kepada para penyimak. Penelitian ini bertujuan untuk mendeskripsikan perkembangan teknologi komunikasi dan bahasa yang terekam dalam lirik lagu populer. Prosedur penelitian yang dilakukan meliputi tahap seleksi dan konfirmasi lagu-lagu yang liriknya akan dikaji, melakukan reading text untuk menemukan teks-teks yang terkait dengan penggunaan alat komunikasi dan bahasa, serta melakukan analisis intertekstual terhadap teks (lirik lagu) yang diambil dari lagu yang berbeda untuk mengamati adanya hubungan antarteks. Hasil penelitian ini memperlihatkan bahwa perkembangan teknologi komunikasi dapat ditelusuri melalui lirik-lirik lagu populer Indonesia, mulai dari radio amatir, telepon kabel, radio, pager, telepon seluler dengan pesan teks, jaringan internet hingga media sosial. Perkembangan bahasa sebagai implikasi dari penggunaan teknologi komunikasi ditunjukkan melalui penggunaan bahasa khusus dalam berkomunikasi yang muncul dalam bentuk istilah, kode, ungkapan, dan kosakata baru. Intertekstualitas yang terdapat dalam beberapa lagu-populer menggambarkan adanya kemiripan situasi, yakni proses perkenalan dan hubungan percintaan yang terbangun melalui penggunaan alat dan media komunikasi, serta perasaan yang disebabkan oleh gangguan bunyi alat komunikasi.

Kata kunci: lagu, teknologi, komunikasi, dan bahasa.

\section{A. PENDAHULUAN}

Manusia merupakan makhluk sosial yang selalu hidup di tengah masyarakatnya. Untuk memenuhi kebutuhannya, manusia senantiasa memerlukan bantuan orang lain. Oleh karena itu, manusia perlu menyampaikan pesan kepada orang lain agar orang yang dituju tersebut memberi tanggapan.

Pokok dari komunikasi adalah penyampaian pesan dari penyampai ke penerima pesan. Dalam ilmu komunikasi, terdapat dua paradigma utama dalam memandang komunikasi. Pertama, melihat komunikasi sebagai transmisi pesan. Kedua, memandang komunikasi sebagai pengonstruksian pesan yang memproduksi makna (encode) dan penerjemahannya (decode). Proses encode oleh si penyampai dan decode oleh si penerima dilakukan secara bergantian menyebabkan terjadinya pertukaran makna (Fiske, 2011: 8-9).

Paradigma yang memandang komunikasi sebagai proses encodedecode ini tidak hanya terjadi melalui komunikasi secara langsung melainkan juga melalui media yang digunakan untuk menyampaikan pesan. Media merupakan perantara yang memuat pesan yang dikonstruksi oleh penyampai kepada penerima.

Definisi teks yang dimaksud tidak terbatas pada teks tertulis yang dapat dibaca dari cetakan di atas kertas. Teks yang dimaksud adalah suatu hal penting dalam setiap sistem budaya adalah konstruksi dan konsumsi teks. Mengacu pada Ricoeur, Shurmer-Smith berpendapat bahwa telah diterima untuk memperluas istilah 'teks' melampaui tulisan/cetakan di atas kertas. Teks 
dapat berupa segala sesuatu yang memiliki tingkat ketahanan/ kelanggengan dalam mengkomunikasikan makna. Oleh karena itu, seseorang dapat 'membaca' lanskap, desain perkotaan, bangunan, tampilan ruangan, film, lukisan, iklan TV, siaran berita, film dokumenter atau opera sabun sebagaimana seseorang membaca buku, leaflet atau peta (Shurmer-Smith, 2002: 123).

Teks merupakan berbagai representasi (Shurmer-Smith, 2002: 27). Representasi yang dimaksud di sini adalah penyajian yang memuat makna yang mencerminkan referensinya. Bass dalam Shurmer-Smith, 2002: 126) menegaskan teks sebagai sebuah produk yang dirancang manusia dengan demikian produk apapun yang dihasilkan manusia dan dapat "dibaca" disebut teks.

Ricoeur (dalam Shurmer-Smith, 2002: 214) memaparkan bahwa teks memiliki bentuk yang beragam berdasarkan karakteristik daya tahan (lamanya) teks dalam menyampaikan pesan yang dapat dibaca. Mulai dari yang permanen (tetap tak berubah) misalnya lukisan, film, dan bangunan yang dijaga bentuk aslinya hingga yang relatif cepat berubah, seperti lanskap dan desain perkotaan. Sejalan dengan pendapat tersebut, Shurmer-Smith (2002: 88) menyatakan bahwa terdapat teks yang berwujud hal-hal yang relatif permanen misalnya tulisan, lukisan, film, rekaman musik, lanskap, dan desain interior. Namun, ada pula teks yang dapat direplikasi, misalnya pertunjukan teater, ritual, perayaan, atau kegiatan-kegiatan yang terencana.

Teks dapat "dibaca", artinya dapat ditafsirkan atau diinterpretasi. Pentingnya keberadaan teks tidak hanya untuk memahami maksud penulis namun juga melatih kemampuan interpretasi pembaca (Shurmer-Smith, 2002: 50). Teks dapat digunakan untuk mengekspresikan rasa gembira, takut, kecewa, dan berbagai perasaan lainnya (Shurmer-Smith, 2002: 89). Teks yang disebarkan ke khalayak luas menimbulkan intersubjektivitas, yakni kesamaan posisi subjek dalam memandang atau membaca teks tersebut.

Lirik lagu sebagai teks hasil karya penulisnya memuat makna (encode) yang disampaikan pencipta lirik lagu agar dapat ditafsirkan (decode) oleh penyimaknya. Fenomena penggunaan alat komunikasi di suatu era adalah teks yang "dibaca" oleh penulis lagu dan dituangkan dalam lirik lagu ini adalah proses encode. Sementara aktivitas menyimak, membaca, mendengar, dan menafsir lirik lagu yang dilakukan oleh pendengar atau peneliti adalah proses decode. Penafsiran (decode) ini dapat membentuk makna baru pada sebuah teks, bahkan berkembang lebih luas membentuk spektrum pemaknaan (polisemi) sehingga dianggap melenceng jauh dari pesan awal pembuat teks.

Teks dapat diinterpretasi menurut pengamat maupun dijelaskan dengan teks lain. Lirik lagu populer dalam kajian ini diinterpretasi menurut penulis 
Handep, Vol. 2, No. 1, Desember 2018

sebagai pengamat dan warga internet (warganet) yang menyimak tayangan videonya di youtube.com. Pembacaan bersama dari penulis dan warganet ini dimaksudkan sebagai penerapan dari pendekatan intersubjektivitas pemaknaan khususnya terhadap lirik lagu tersebut. Beranjak dari definisi ini, lirik lagu merupakan teks yang menyampaikan makna dan dimaknai oleh penyimaknya, baik pada masa popularitasnya maupun masa-masa setelahnya.

Lirik lagu pop ${ }^{1}$ merupakan produk budaya populer. Beberapa alasan pentingnya dilakukan kajian lirik lagu pop adalah karena budaya populer cepat hilang dan dilupakan di saat lagu pop terbaru muncul. Padahal jangkauannya yang luas dapat memberi kesan atau makna pada banyak orang yang menjadi pendengarnya. Reinterpretasi atas lirik lagu populer dimaksudkan untuk menghadirkan kembali kesan terhadap suatu masa, saat lagu tersebut populer. Selain itu, pengungkapan kembali budaya populer diperlukan untuk menghubungkan generasi saat ini dengan sejarah perkembangan peradaban masyarakat. Kajian budaya populer berperan sebagai jembatan apresiasi lintas generasi pada budaya bangsanya. Terlebih di era digital saat ini, jejak budaya yang pernah populer di zamannya dapat ditelusuri melalui format digital di media sosial, di

1 Pop didefiniskan sebagai musik populer dengan gaya modern (Oxford Learner's Pocket Dictionary Fourth Edition, 2008). antaranya youtube.com. Media sosial merupakan tempat warganet melakukan sosialisasi diri. Tidak hanya dalam arti komunikasi, namun sekaligus menjadi media perbincangan pribadi ataupun media untuk penyiaran publik (Miller dalam Bayuardi, dkk., 2018: 103).

Kajian budaya populer sekaligus menjawab pertentangan budaya luhur dan budaya populer. Budaya populer cenderung diremehkan, dianggap merusak budaya luhur, menyajikan pertunjukan budaya massal yang murah, serta mengarah pada konsumerisme. Gans (1974: 3) berpendapat kajian budaya populer penting untuk dilakukan karena penekanannya lebih dari sekadar perkembangan media dan konsumsi barang. Budaya populer benar-benar menggambarkan kehidupan dan tujuan hidup masyarakat serta menunjukkan budaya suatu masyarakat dan bangsa dalam rekaman sejarah dan peradaban budayanya.

Pada kajian ini, reinterpretasi lirik lagu pop dimaksudkan untuk menunjukkan bahwa pesan yang dimuat dalam karya seni populer dapat digunakan untuk mengetahui perkembangan penggunaan teknologi komunikasi. Munculnya teknologi komunikasi yang secara eksplisit disebutkan dan digunakan dalam lirik lagu dapat dilihat sebagai hal yang memang populer pada setiap zamannya. Reinterpretasi lirik lagu-lagu pop ini menunjukkan bahwa lagu populer merekam jejak teknologi yang digunakan pada zaman di saat lagu itu diciptakan. Suatu produk hasil cipta 
yang sederhana mudah diabaikan, padahal darinya dapat diperoleh pesan, makna, dan informasi khususnya bagi orang-orang yang menghayatinya dan memaknainya.

Penelitian analisis lirik lagu telah banyak dilakukan dengan pendekatan lain, misalnya analisis semiotika. Di antaranya "Satisfaction and Pop: Britney Spears (Oops! ...I Did It Again, 2000)'. Penelitian ini membahas kiprah Britney Spears sebagai artis remaja perempuan dalam musik pop dan budaya populer Amerika di akhir 1990an yang mengeksplorasi sensualitas remaja perempuan (Greene, 2014: 74). ${ }^{2}$ Contoh lain adalah interpretasi lirik lagu "Judas"yang dinyanyikan oleh Lady Gaga. Menurut Silalahi (2015: 9), tema lagu "Judas" adalah cinta dan pengampunan. Lagu ini menunjukkan bahwa semakin banyak manusia yang mencintai dosa dan menjauh dari pertobatan.

Kajian yang telah dilakukan pada lagu Britney Spears dan Lady Gaga tersebut berbeda dengan kajian ini. Pertama, penelitian ini memilih satu tema, yaitu penggunaan alat komunikasi dan dipergunakannya kosakata/bahasa yang khas dalam berkomunikasi, yang secara eksplisit disebutkan dalam beberapa lirik lagu pop di Indonesia. Kedua, analisis

2 Tema satisfaction dalam buku ini merangkum beberapa kajian lagu pop Amerika yang berasal dari berbagai genre, yaitu rock, punk, soul, dan pop. Kajian lagu Britney Spears mewakili makna satisfaction dalam genre pop. reading text dengan pendekatan intersubjektif. Kajian ini lebih menekankan penempatan sudut pandang yang sama terhadap suatu objek. Peneliti dan warganet memiliki posisi yang sejajar sebagai penyimak lagu pop tersebut, artinya penulis menggunakan native point of view dari warganet. Ketiga, kajian lirik lagu pop belum pernah dikaji untuk melihat perubahan teknologi komunikasi dan bahasa sebagai salah satu unsur budaya.

Lirik lagu merupakan produk seni populer yang dapat digunakan untuk merawat ingatan kolektif tentang fenomena penggunaan teknologi komunikasi dan bahasa yang mengalami perubahan seiring perkembangan zaman. Mengapa lirik lagu? Lagu lebih mudah diwariskan dibandingkan dengan bentuk karya seni yang lain. Jangkauan ingatan atau kenangan terhadap lagu-lagu tertentu pun cenderung lebih panjang. Selain itu, lagu lebih mudah diakses dan dapat menyebar luas di masyarakat dibandingkan dengan jurnal atau karya ilmiah yang biasanya hanya diakses kalangan akademisi.

Dalam hal ini, seni tidak selalu hanya untuk seni tetapi kreator seni pun ingin hasil karyanya dapat diterima dan diapresiasi masyarakat luas. Cara yang efektif bagi kreator seni untuk menyebarluaskan karyanya adalah dengan bergandengan tangan dengan industri yang memiliki sumber daya produksi massal, distribusi, dan pemasaran sehingga karya tersebut dapat dinikmati oleh banyak orang dan menjadi semakin populer. 
Urgensi penelitian ini adalah pertama, menunjukkan bahwa manusia menyampaikan makna (encode) pada produk apapun yang dihasilkannya. Sebaliknya, manusia juga menafsirkan dan menginterpretasi (decode) apapun yang dapat 'dibaca'. Kedua, memperkenalkan definisi teks yang lebih luas, tidak hanya berupa aksara pada media tertulis. Teks dapat berupa segala sesuatu yang dihasilkan manusia dan bisa dibaca, diinterpretasi atau ditafsirkan.

Lirik lagu berperan sebagai media komunikasi yang dapat mengekspresikan fenomena sosial yang ditulis oleh pengarangnya. Dalam kajian ini, penulis menelisik lirik-lirik lagu populer di Indonesia yang secara ekplisit mengangkat fenomena penggunaan alat komunikasi dan kosakata/bahasa khas dalam berkomunikasi di era 1980-an, 1990-an hingga 2010-an.

Dengan menyusun lagu-lagu populer secara kronologis, dapat dikaji perubahan media, sistem teknologi komunikasi, dan bahasa yang terjadi di Indonesia. Meskipun objek yang diamati dalam penelitian ini adalah lirik-lirik lagu yang merupakan karya seni, analis yang dilakukan oleh penulis tidak menggunakan parameter estetika $^{3}$ melainkan pada teks lirik lagu secara literal (harfiah) untuk

\footnotetext{
${ }^{3}$ Definisi estetika adalah kajian tentang proses yang terjadi pada subjek, objek, dan nilai terkait pengalaman, properti, dan parameter kemenarikan dan ketidakmenarikan (Junaedi, 2016: 14)
}

menjelaskan perubahan cara komunikasi secara kronologis dan dampaknya pada perubahan sistem bahasa sebagai implikasi penggunaan teknologi komunikasi di masingmasing era yang diwakili lagu tersebut.

Teknik pengumpulan data dilakukan dengan melacak lirik-lirik lagu populer Indonesia yang secara eksplisit menyebutkan alat komunikasi dan mengandung kosakata khas dalam berkomunikasi. Sumber liriklirik lagu yang dikaji tersebut diperoleh melalui media sosial berbasis audio visual, yakni youtube.com. Peneliti menafsirkan lirik-lirik lagu tersebut secara intersubjektif, yang berarti peneliti menempatkan sudut pandangnya pada posisi yang sama dengan penyimak lirik lagu pada umumnya. Tujuannya adalah untuk menggali dan memahami konteks sosial di saat lagulagu tersebut populer di Indonesia. Analisis intertekstual diterapkan pada teks-teks yang menyampaikan makna tentang penggunaan alat komunikasi dan kosakata/bahasa khas dalam berkomunikasi. Prosedur di atas tidak menggambarkan urutan analisis dan dapat dilaksanakan secara simultan.

Lirik lagu popular menjadi lokus penelitian ini. Fokus kajian ini adalah pertama, menganalisis perkembangan penggunaan alat komunikasi yang terekam dalam lirik lagu pop Indonesia. Kedua, menganalisis kosakata/bahasa khas yang terekam dalam lirik lagu pop Indonesia yang muncul sebagai akibat dari penggunaan alat komunikasi serta 
implikasinya pada perkembangan bahasa.

Bahasa merupakan unsur penting pembentuk budaya ${ }^{4}$. Melalui bahasa, sistem simbolik dan tanda yang digunakan untuk mengungkapkan atau mengekspresikan berbagai gagasan dan pengetahuan dikomunikasikan. Aspek perilaku dalam interaksi dan unsurunsur kebudayaan sebagai kesatuan utuh tidaklah diwariskan secara biologis melainkan melalui sarana bahasa (Neuman, 2002: 49). Sistem bahasa dalam setiap kajian kebudayaan menjadi penting karena kebudayaan tidak hanya berwujud konkret (tangible) tetapi juga berwujud abstrak berupa perilaku, bahasa, dan gagasan atau pengetahuan (Ahimsa-Putra, 2012: 2) $)^{5}$.

Komunikasi mengalami evolusi seiring dengan peran teknologi yang menjadi wahananya. Komunikasi dari zaman ke zaman menjadi lebih efektif bersamaan dengan munculnya bahasa tulisan. Sebuah rangkuman oleh Rogers (1986: 25-26) secara garis besar menggambarkan kronologi komunikasi

4 Koentjaraningrat (2002: 218) berpendapat bahwa ada tujuh unsur kebudayaan yang dapat ditemukan pada semua bangsa di dunia, yaitu bahasa, sistem pengetahuan, organisasi sosial, sistem teknologi, sistem mata pencaharian hidup, sistem religi, dan kesenian

${ }^{5}$ Menurut Ahimsa-Putra, kebudayaan memiliki empat aspek, berturut-turut dari yang konkret ke yang abstrak adalah: (a) aspek fisik atau budaya material; (b) aspek perilaku atau budaya perilaku; (c) aspek kebahasaan atau bahasa, dan (d) aspek gagasan atau budaya pengetahuan (Ahimsa-Putra, 2012: 2) manusia yang jika dirangkum dimulai dari bahasa lisan dan lukisan gua, era tulisan, era media tulisan cetak, telekomunikasi hingga komunikasi interaktif.

Tulisan ini mengangkat beberapa hal yang seringkali terlepas dari perhatian saat menikmati lagu-lagu populer. Kondisi sosial budaya pada setiap zaman seringkali tercermin dari berbagai karya seni populer yang diciptakan di zaman tersebut. Proses penciptaan karya seni dapat terinspirasi atau mendapat referensi dari kehidupan sehari-hari atau pengalaman yang dituangkan seniman dalam karyanya. Salah satu karya seni tersebut adalah lirik lagu populer yang merupakan karya sastra kontemporer dan ditulis secara bebas sebagai pesan yang termuat dalam sebuah lagu.

\section{B. HASIL DAN BAHASAN}

1. Penggunaan Alat Komunikasi Dalam Lirik Lagu Sebagai Teks untuk Memahami Perkembangan Teknologi Komunikasi di Indonesia

Radio merupakan teknologi komunikasi yang paling luas digunakan di masa awal berdirinya negara Indonesia. Pada tahun 1980-an, teknologi komunikasi melalui gelombang radio sering digunakan secara interaktif dengan perangkat yang disebut Handy Talkie (HT) atau dikenal dengan radio amatir. Lagu dari Farid Hardja yang dirilis tahun 1983, menunjukkan penggunaan HT untuk komunikasi dalam pergaulan mudamudi saat itu. 
"Berkenalan nama samaran

Lewat gelombang radio 5973

angka untuk kamu

Ber QSO lalu cherio

Cup ah cup ah cup ah cup

Di udara aku menunggu

Kau panggil namaku

Kupanggil namamu

Papa Alpha Charlie Alpha

Romeo

Mengajakku gombal di udara

Memang cinta asyik dimana saja

Walau di angkasa

Hahaha ... break break...

Lima Oscar Victor Echo,

apakah monitor?

Suara mesra memanggilmu

Perlu dan bercumbu"

(Sumber:https://youtube/

8c0kT1Yxoyc, diakses pada 13

Oktober 2018).

Dari ribuan komentar dan pendapat dari warganet tentang lagu dan penampilan video klipnya, penulis mencuplik beberapa di antaranya, seperti berikut ini

Fahmi Fsyah [2016]:

"papa alpha charlie alpha romeo

$=$ PACAR...

Shanty Nio Alvira [Juni 2018]:

"nonton warkop DKI jd nyari

lagunya .. enak d denger lagunya

(-)(-) anak zaman now mana ada

yg kenal lagu beginian Di sini

YC3CM Salam rindu buat kamu cherio...."

Auliya Hardiman [2017]:

"ke inget main intercom tahun 90 an....."
M. Namo [2017]:

"ROGER,... ROGERRR,. copy darat yuu :-) aq sepuluh dua tiga dlu ea... :-D"

Si kodok hoax (2017):

"jaman dulu cari kenalan lewat radio $c b$. sekarang udah pake bbm wechat whatssapp."

Bentuk komunikasi menggunakan radio amatir atau $\mathrm{HT}$ bersifat half duplex, yakni komunikasi dua arah namun dengan proses transmisi dan menerima data secara bergantian (Ramesh, 2009: 147) ${ }^{6}$. Dengan demikian cara kerjanya tidak memungkinkan untuk berbicara dan mendengar pesan secara bersamaan.

Hampir berbarengan dengan populernya radio amatir, di pertengahan 1980-an pesawat telepon mulai lazim digunakan untuk kepemilikan pribadi di Indonesia. Saat itu, permasalahan yang seringkali ditemukan atau muncul pada lirik lagu populer bergenre rock yang dinyanyikan oleh Nicky Astria berjudul "Tujuh Kali Berdering”. Lagu yang dirilis tanggal 19 Agustus 1985 ini menggambarkan kekesalan seseorang

6 Bentuk komunikasi dibagi tiga kategori, yaitu simplex, half duplex dan complex duplex (Ramesh, 2009: 147). Simplex merupakan bentuk komunikasi antara dua belah pihak dengan sinyal terkirim satu arah, contoh siaran radio. Half duplex merupakan bentuk komunikasi antara dua belah pihak dan dua arah, secara bergantian antara yang mentransmisikan dan menerima data. Contoh walkie-talkie. Full duplex merupakan bentuk komunikasi antara dua belah pihak yang saling mengirim dan menerima informasi dalam waktu bersamaan. Model ini umumnya memerlukan dua jalur komunikasi, contoh telepon. 
yang berkali-kali menerima panggilan salah sambung. Salah sambung terjadi karena penelepon salah memutar nomor telepon atau penelepon tidak menyadari bahwa nomor kontak yang ia hubungi berbeda dari yang dimaksud. Penelepon merasa memutar nomor yang benar padahal terhubung dengan orang yang salah maka ia mencoba berulang kali. Jika salah sambung terjadi berkali-kali, akan membuat pusing dan pening orang yang menerima, seperti terekam pada lirik lagu ini.

"Ringring telpon berdering

Tujuh kali berdering

Sudah tujuh kali salah sambung

Mungkin Anda sedikit linglung...

725250375

Kau selalu bertanya

Nomor yang itu

Dan yang itu lagi

Aku pusing pening, tambah pening

Ini mungkin sinting"

(Sumber: https://youtu.be/

UYbztfwcLxA, diakses pada13

Oktober 2018).

Berikut komentar dan pendapat warganet tentang penampilan lagu tersebut, berupa pengalaman atau kenangan serta pengetahuan warganet tentang yang berkaitan video klip dan lirik.

Jay Arfin [2012]:

"jd igt waktu lebaran di th 80an...krn lagu ini trend diwktu itu...selama ramadhan ...selecta pop...lagu ini srg nongol di tvri...haaaaajd pengin kbli ke wktu kecillll...hikhik..sipppp.sippp teh nickyyyy."
Hery Setiawan [2012]:

"Aha ..... Sekitar tahun 1985, lokasi hotel Garuda Yogya yg baru selesai renovasi. Thanks for uploading this clip."

Pada era yang sama di tahun 1985, telepon menjadi atribut komunikasi di kalangan anak muda yang sedang menjalin hubungan pacaran atau sedang jatuh cinta. Penggalan lagu 'Kugadaikan Cintaku' yang rilis tahun 1986 dinyanyikan oleh Gombloh menyebutkan dua perangkat teknologi komunikasi, yaitu telepon dan radio. Bagian lirik yang dimaksud sebagai berikut.

"Di radio aku dengar

lagu kesayanganmu

Kutelepon di rumahmu

Sedang apa Sayangku

Kuharap Engkau mendengar

dan kukatakan rindu...

Di radio aku dengar

lagu kesayanganmu

Ku tutupi telingaku dengan dua tanganku

Biarlah cepat berlalu dan,

Ku gadaikan cintaku”

( Sumber: https://www. liriklaguindonesia.com/di-radiogombloh, diakses pada 13 Oktober 2018).

Sama seperti lagu "Tujuh Kali Berdering", lagu yang dinyanyikan Gombloh ini juga menyebutkan alat komunikasi berupa telepon sebagai teknologi komunikasi yang populer dan dianggap bergengsi di film, sinetron televisi dan percakapan sehari-hari di 
Handep, Vol. 2, No. 1, Desember 2018

masa itu. Berikut adalah komentar dari warganet mengenai lagu "Kugadaikan Cintaku".

Ari Kirun 2 [2017]:

"ternyata diindonesia pernah ada masa keemasan karya seni, dimana penyanyi \& model video klipnya sama sekali tidak ada yg cakep \& keren. tapi karyanya begitu dihargai, tidak seperti sekarang."

Mama Shinta [2017]:

"Sudah almarhum semua ... rindu deh zama dulu rasa mau rewind balik i miss thn 80 n 90 an."

Muhamad Solioyong [2015]: "mantap lagunyaa...lagu ini aku blom lahir,tpi ktny lagu gombloh populer thun 80an."

Criss Bank [2017]:

"I song \& can bring back 1000 memory (2) sd"

Barfiansyah Sheivha [2017]:

"Aku sangat suka lagu ini... dulu hanya bisa dengar diradio hehe”

Baik lagu "Tujuh Kali Berdering" maupun "Kugadaikan Cintaku", keduanya mengangkat fenomena penggunaan telepon. Artinya ada pengalaman bersama mengenai penggunaan telepon pada masa itu. Posisi sebagai sesama pengguna telepon yang dialami oleh kedua penulis lirik tersebut menimbulkan intersubjektivitas. Namun, pemaknaan telepon mengalami polisemi (kata yang bermakna lebih dari satu). Pada lirik lagu "Tujuh Kali Berdering", telepon dianggap sebagai pengusik dan pembuat "pusing pening" akibat panggilan salah sambung. Sebaliknya, pada lagu "Kugadaikan
Cintaku", telepon bermakna perangkat yang membantu untuk menyampaikan harapan dan perasaan, seperti yang dinyatakan dalam lirik "kuharap kau mendengar dan kukatakan rindu".

Lagu "Kugadaikan Cintaku" juga menyinggung perangkat teknologi komunikasi berupa radio sebagai penyampai pesan. Di sini terlihat "lagu kesayanganmu" yang diputar di radio menjadi "teks" bagi tokoh aku dalam lirik di atas. Ia memuat makna sesuatu yang dicintai oleh tokoh "sayangku". Lagu yang sama bisa jadi akan memberikan makna yang berbeda bagi pendengar lain.

Di akhir 1990-an muncul alat komunikasi berbasis teks, yakni pager yang dialihbahasa ke dalam bahasa Indonesia dengan penyeranta. Alat komunikasi ini sempat populer di kalangan anak muda saat itu, namun tidak bertahan lama. Pager pun cenderung hanya populer di kalangan masyarakat "kelas atas" sehingga atribut teknologi ini menjadi simbol status bagi pemiliknya. Band beraliran musik rap bernama Sweet Martabak pernah menggambarkan repotnya menggunakan pager dalam lagu berjudul "Ti Di Dit". Berikut cuplikan lagunya.

"Ini sudah pagi tapi ku tak masuk sekolah

Maklum pacarannya eh sama yang udah kuliah

Tapi sebentar pagernya berbunyi Malu dong, anak masa kini Gak taunya masih aja beritanya salah 
Lama-lama barang ini bisa bikin ku marah

Kabar yang kutunggu pun tertulis di pagerku

Masih aja, Cindy melulu

Di mana ya pacarku, koq belum mengabari

Apa tuh pesan, ke pager yang lain Kalau begini ku tak tahan lagi

Ku jadi males kalo mau bikin janji Bikin kesel ah, mending dari tadi ngga bawa pager

Tidit pagernya berbunyi tidit tidit begitu bunyinya

Kadang punya pager bikin senang Kadang bikin resah, kadang bikin marah (2x)"

(Sumber: https://youtu.be/ qZ3pceoly80, diakses pada 13 Oktober 2018).

Dari komentar warganet atas lagu tersebut tampak sekali bahwa warganet memiliki banyak kenangan di masa ketika pager digunakan. Mereka teringat kembali ke masa itu, bahkan menghubung-hubungkannya dengan peristiwa-peristiwa yang sangat personal. Secara tidak langsung, komentar-komentar itu mengingatkan akan periode waktu tertentu serta segala hal yang sedang digunakan dan dialami di masa itu.

Ginawan Zavira [2015]: "pager, tamagochi,, faxmail,, friendster,,, wartel... hehehe awal 2000an sekarang 2016"

Mr. Shigeo Tokuda, PhD [2017]: "dulupager gadget keren banget yah... , jadi inget punya bokap, starpage. hahahhaha...“
Penganguran berat [2017]: "jaman peger. mo kirim pesen via operator dulu...apalagi mo janjian." Adam Ucin [2017]: "Buset ini lagu jaman TK, jaman segitu lagi tenarnya pegger, itupun gak semua orang punya pagger, boro2 hp kaya sekarang."

Bluekuthuk Blue [2017]: "Wkwkw. ingat jaman SMA dulu punya Pager udah keren banget."

Dudi Gunawan [2017]: "hebaaat. ini musik waktu SMU..1995-96.”

Ramdhani Surya Kusumah [2016]: "wuaduuhh pager dong, zaman skrg adanya hp, anak jama dulu kayanya gak tau apa itu pejer haha."

Markus Srihardi [2016]: "Belom ada HP, tapi tetep kekinian jaman itu hahaha top."

Erwin Saleh [2015]: "Ha ha inget jaman dulu gue.punya pager ga ada yg hubungin sama sekali hihihi .gue laga 2 ada nada panggilan aja .padahal gue yg bunyikan naik bis org pada lihat .dulu punya pager bener cewe pada ngeluruk hahaha."

Wahyu Septian [2016]: 'Ini nih salah satu legend musik Indonesia, jaman blm ada smartphone. Anak sekarang ga ada yang tau apa itu pager...."

Pager tidak terlalu lama digunakan oleh masyarakat dan tidak sempat mewabah sampai ke semua lapisan masyarakat. Teknologi tersebut tergantikan oleh telepon seluler yang mulai digunakan sekitar 1995. 
Handep, Vol. 2, No. 1, Desember 2018

Pada awalnya, telepon genggam ini juga merupakan simbol status sosial karena harga dan biaya pulsanya yang mahal. Telepon genggam hanya dapat dimiliki oleh kelompok masyarakat tertentu.

Di awal tahun 2000, penggunaan telepon seluler semakin populer dan mulai menjangkau ke semua lapisan masyarakat. Hal ini terjadi seiring dengan semakin banyaknya penyedia atau operator jaringan telepon seluler, serta lebih murahnya tarif pulsa. Sekitar tahun 2001, para pengguna telepon seluler mulai menggunakan jasa operator yang menyediakan pesan teks (SMS). Dengan demikian, telepon seluler dapat berfungsi sebagai alat komunikasi realtime saat digunakan untuk menelepon. Namun, perangkat ini sekaligus berfungsi pula untuk melakukan komunikasi tunda karena bisa digunakan untuk mengirim dan menerima pesan teks singkat.

Kondisi seperti ini pun sempat terekam dalam lirik lagu Slank, yang berjudul "I Miss You But I Hate You" dalam cuplikan lirik lagu berikut.

“... Hampir setiap malam hari

Di dalam tidurku,

Sering memimpikan kamu...

Banyak pulsa untuk menelpon kamu

Banyak pesan yang aku tinggalkan Tapi di mana kamu aku nggak tahu Jarang di rumah kebanyakan di jalan

Baru aja kubuka mata

Terbangun pagi-pagi

Langsung kepikiran kamu
Setiap bunyi berdering

Langsung ku angkat telponku

Berharap itu dari kamu

Berkali-kali aku sms kamu,

Berkata mesra yang aku ucapkan, Kamu nggak tahu apa nggak mau tahu. Nggak ada kabar nggak ada penjelasan..." (Sumber: https://youtu.be/ 43CRxTIOoDU, diakses pada 13 Oktober 2018).

Lagu "I Miss You But I Hate You" menggambarkan penggunaan alat komunikasi berupa telepon seluler (ponsel) yang tidak hanya digunakan untuk menelpon tetapi juga untuk berkirim pesan singkat. Penggalan lirik lagu di atas berisi curahan hati seseorang yang ingin menunjukkan pengorbanan yang telah dilakukannya untuk menghubungi sang pacar. Hal itu terungkap pada lirik "Banyak pulsa untuk menelponkamu, banyak pesan yang aku tinggalkan". Pulsa dalam besaran minimal tertentu harus tersedia di kartu SIM yang akan kita gunakan untuk membuat sambungan telepon. Jika pulsa minimal tersebut tidak tersedia, sambungan telepon tidak dapat dilakukan. Semakin sering dan semakin lama frekuensi waktu bertelepon tentu akan semakin menguras pulsa. Kehadiran fitur SMS (layanan pesan singkat) yang tersedia dalam teknologi komunikasi berupa ponsel menjadi sarana alternatif untuk melakukan komunikasi dengan biaya yang lebih murah.

Di waktu yang hampir bersamaan, internet dan media sosial mulai 
merambah hampir ke seluruh lapisan masyarakat. Fenomena ini cenderung terjadi di perkotaan, seiring dengan menjamurnya layanan internet. Aplikasi untuk chatting atau berbincang di dunia maya yang populer di tahun 1998 ialah mIRC. T-Five, salah satu grup vokal di Indonesia, memelesetkan mIRC ke dalam judul lagu "Malam Ini Si Ramli Chatting Lagi". Berikut ini adalah cuplikan lirik lagunya.

"Si Ramli raja chatting punya gebeten namanya Putri Bikin Ramli bilang wo ai ni emang Ramli raja chatting Terbayang wajah Putri oleh Ramli di mato Tak tahan Ramli cape cape ingin basuo Onde mande rancak bana Putri iko yo Ramli tarui bacarito" (Sumber: https://youtu.be/ c6tw3UFvtuI, diakses pada13 Oktober 2018).

Aplikasi komputer mIRC begitu banyak meninggalkan kenangan bagi para warganet yang menggunakan platform tersebut. Berikut ini adalah bukti antusiasme warganet mengomentari video klip dan lirik lagu tersebut.

Hanung Indra Kusuma [2014]: "Lagunya asik banget.. Jaman duli miRC memang ngehits bgt.. MiRC mbahnya medsos.."

SKYWALKER SKYWALKER [2015]: "bunyi internet connection nyaudah lama banget itu... Jd inget jaman dulu pake telkomnet instant."
Jodhi Wirawan [2018]: “Jaman ongkos koneksi internet lagi mahal mahal-nya ama dan gak secepet sekarang."

Kiki Rizkianto [2017]: "lagu lama 2003an ini, jaman jaman chating nanya asl pls hahaa."

WSCMedia Banten [2018]: "Lagu ini 2009 belum terlalu pas liriknya buat kehidupan dulu secara luas, ternyata lagu ini memprediksi masa depan kecanduan medsos secara merata di masyarakat mulai meledak berkisar tahun 2014 ya.....sampai sekarang bener-bener kejadian ya. keren bang saykoji. Dan sekarang udah di awal tahun 2018."

Afrida Ilsya [2018]: “2008 belum paham akan lagu ini, sebab dulu sosmed yang beredar hanya facebook dan friendster org2 saat itu belum kecanduan gadget dan sosmed. Skrg lagu ini maksudnya untuk 10tahun kemudian yaitu skrg ini bener 2 kenyataan dimana semua org sudah kecanduan namanya ONLINE."

Nastasha Evangelista [2018]:

"Andai saykoji yg bikin lirik pasti lagu dj indonesia bagus" :') Ini liriknya aja udah ngeramal masa depan,,, makan siang pun aku cari sinyal wifi,,, padahal pada saat itu belum begitu menjamur hp yg bisa connect wifi wkwkwkk,,,"

Dedi Munandar [2018]: "Jdi inget belajar komputer pas smp tahun 2006an.... msh beljar pya email yahoo atau rocketmail... dlu ga tau buat apa.skrng 2018, 12 tahun lalu 
Handep, Vol. 2, No. 1, Desember 2018

skrng tau gunanya email...dan lwt $h p . . "$

Momo Chu [2018]: "maklum resolusinya kecil. lagu ini lahir dijaman $3 G$ HSDPA+ lagi booming."

Lirik lagu bertajuk mIRC di atas menunjukkan di saat itu terjadi tren komunikasi dengan menggunakan layanan internet. Pada lirik lagu T-Five di atas, "raja chatting" bermakna orang yang gila (terobsesi) di dunia maya. Perbincangan yang berlangsung di dunia maya pun menjadi awal perkenalan yang dilanjutkan dengan pertemuan dalam situasi nyata atau tatap muka secara langsung. Dengan demikian, imajinasi figur seseorang yang pada akhirnya dijumpai ini telah hadir sebelumnya meskipun hanya berdasarkan citra yang ditampilkan di dunia maya.

Kebutuhan penggunaan teknologi komunikasi ternyata tidak hanya bersifat personal tetapi juga mendorong munculnya kebutuhan untuk berinteraksi dan bertemu dengan orangorang baru. Dunia interaksi sosial berpindah dari lingkungan sosial yang mempertemukan orang dalam situasi tatap muka ke dalam ruang seluas layar komputer. Sejak chatting mulai marak dilakukan, terbentuklah dualitas dunia interaksi sosial, yakni dunia nyata dan dunia maya. Semula mIRC adalah aplikasi yang dirancang untuk memenuhi kebutuhan berkomunikasi di antara para penggunanya tanpa harus meninggalkan meja komputer, namun kemudian berkembang hingga menciptakan ruang-ruang maya yang di dalamnya terjadi pertemuan orangorang untuk berinteraksi sosial.

Dari hari ke hari, media yang digunakan untuk mengakses internet pun semakin beragam. Perkembangan media komunikasi tersebut terjadi seiring dengan inovasi teknologi yang hadir untuk merespon kebutuhan komunikasi yang kian praktis. Internet yang pada mulanya hanya dapat diakses dengan personal computer (PC) dan komputer jinjing (netbook dan laptop), kemudian bisa diakses pula dengan perangkat elektronik pintar atau gawai (gadget) berupa smartphone dan tablet.

Media untuk mengakses internet ini dapat ditemukan dalam lagu berjudul "Online" yang dibawakan oleh seorang rapper yang menamakan dirinya Saikoji. Berikut ini nukilan dari lirik lagunya.

"Siang malam ku selalu menatap layar terpaku untuk online online, Online-online

Tidur telat bangun pagi pagi, nyalain komputer online lagi bukan mau ngetik kerjaan email tugas diserahkan tapi malah buka facebook padahal face masih ngantuk beler kaya orang mabuk pala naik turun ngangguk ngangguk"

(Sumber: https://youtu.be/ XEYkMaxZmIE, diakses pada 13 Oktober 2018). 
Lirik lagu yang dinyanyikan Saikoji juga menyebut salah satu media sosial paling populer di saat itu, yaitu Facebook. Keberadaan media sosial ini tampak pula dalam lirik lagu " $M y$ Facebook" yang dinyanyikan oleh band Indonesia GIGI dengan lirik-liriknya sebagai berikut.

"Berawal dari facebook baruku

Kau datang dengan cara tiba-tiba Bekas kekasih yang lama hilang

Satu dari kekasih yang terbaik

Mungkin waktu yang

ku persalahkan

Mungkin saja keadaan yang salah Terpikir hati untuk mendua

Tapi nurani tak bisa mendua", (Sumber: https://youtu.be/ o9TUjr04LZ8, diakses pada 13 Oktober 2018).

Lagu "Online" menggambarkan perilaku ketergantungan untuk selalu online. Lagu ini menggambarkan bahwa kebiasaan online dalam jangka waktu lama untuk membuka media sosial (facebook) dapat mengintervensi daya konsentrasi seseorang hilangnya fokus saat bekerja, dan ritme biologis yang terganggu sehingga berakibat pada menurunnya produktivitas.

Lagu GIGI berjudul " $M y$ Facebook" menunjukkan fungsi media sosial sebagai ruang pertemuan. Data yang tersimpan di sistem data raksasa berupa internet, yang dilengkapi dengan atribut waktu dan lokasi, menjadi rekam jejak digital sebanyak data yang diunggah seseorang ke dalam dunia digital.
Berikut ini adalah komentar dari para warganet saat mengenang penggunaan Facebook.

Praja Kirana [2017]: “my facebook. kisah aku banget ni.. dpt kenalan cocok.. cantik.. and tangguh..jalan.. nonton.. eh... g tau skarng knp dia menghindar.. ..padahal aku dah trlanjur suka.."

Didit Nugroho [2018]: "Terima kasih dari facebook ku mendapatkan banyak kenalan wanita bahkan jadi pacar sekaligus pdkt dari facebook cuman 1 minggu langsung jadian......."

Sugi Eghi [2018]: “Berawal $d r$ facebook wajah2 lama jaman smk ku telah muncul lg padahal ku tlah jauh dr samarinda alhamdulillah msh ingat smua sama aku thank all by sugie."

Imron Muhammad [2018]: "Berawal dari facebook pacarku direbut orang."

Bayurlor Pkm [2018]:

"Awal adanya sosmed FB, saat itu langsung booming tuh aplikasi, cuma android di masa itu blm ada, adanya hp berbasis IOS, buka FB wajib ke warnet."

Banyak sekali warganet yang memiliki pengalaman menggunakan platform tersebut. Hingga saat ini, facebook memang merupakan aplikasi yang paling banyak digunakan. Facebook digemari banyak orang karena kelengkapan fiturnya. Salah satunya adalah dengan keberadaan fitur berbagi status, yakni berupa tulisan singkat tentang apa yang dipikirkan oleh pemilik akun. Fitur yang tersedia 
Handep, Vol. 2, No. 1, Desember 2018

di facebook pun dianggap dapat menjadi pengganti email karena memungkinkan para penggunanya untuk saling berkirim surat elektronik, baik dokumen yang berupa teks, gambar, maupun video. Setiap orang dapat membagikan apa yang ia pikirkan melalui unggahan statusnya. Pikiranpikiran tersebut kemudian dapat dibaca semua orang yang terhubung dalam jaringan pertemanannya di dunia maya.

Evolusi komunikasi dimulai ketika media sosial dapat diakses melalui perangkat pintar yang berada dalam genggaman. Gadget merupakan wujud dari perkembangan teknologi komunikasi berupa smartphone (telepon cerdas). Perangkat yang pada awalnya hanya berfungsi sebagai alat komunikasi, dalam perkembangannya kemudian dapat menjalankan berbagai fungsi sekaligus (multifungsi). Selain untuk berkomunikasi, gadget juga bisa berfungsi sebagai sumber informasi, pendukung kerja hingga sarana hiburan.

Terdapat lagu tentang gadget yang dinyanyikan oleh Romaria, seorang penyayi cilik berusia 10 tahun. Lagu tersebut berjudul "Main Gadget" yang liriknya dapat disimak berikut ini.

"papa papa bolehkah

bolehkah aku pinjem pinjem laptopnya mama mama bolehkah

bolehkah aku pinjem pinjem handphonenya

aku mau main, aku mau main main games kesukaanku aku mau main, aku mau main daripada ku melamun waktunya belajar aku belajar

waktunya sekolah aku sekolah waktunya ku makan aku pun makan sekarang waktunya ku main gadget jet jet jet gadget jet jet gadget jet jet jet gadget gadget gadget"

(Sumber: https://www. youtube. com/watch? $\mathrm{v}=\mathrm{t} 5-\mathrm{SJ}$ mw 3LYI, diakses pada 13 Oktober 2018).

Gadget tidak hanya memiliki bentuk dan fungsi yang beragam, lagu di atas juga memperlihatkan bahwa kebutuhan akan gadget telah menjangkau hingga ke lapisan usia anak-anak. Dewasa ini anak-anak usia PAUD, TK, dan Sekolah Dasar sudah terbiasa menggunakan perangkat ini, terutama untuk bermain games.

Jika merunut penggunaan alat komunikasi dari masa ke masa, terlihat bahwa telah terjadi perkembangan teknologi dan media komunikasi yang relatif cepat, dimulai dari pager yang cara kerjanya mengadopsi telegram di masa lalu, yakni menyampaikan pesan berupa teks singkat. Komunikasi yang terjadi pun hanya satu arah. Si pengirim menyampaikan pesan kepada orang yang dituju melalui operator tanpa bisa mendapatkan respon atau balasan secara langsung. Orang yang menerima pesan hanya bisa membaca pesan yang masuk ke pagernya. Oleh karena itu, sejatinya pager hanya berfungsi sebagai media penyampai pesan. Kerepotan akan terasa berkali lipat. Selain karena keterbatasan jangkauan dan jumlah provider layanan yang terbatas, si pengirim pesan pun harus menelepon 
operator untuk menyampaikan pesannya. Operator inilah yang selanjutnya mengetik pesan tersebut dan mengirimkannya ke nomor pager yang dimaksud. Otoritas pengiriman pesan ke perangkat pager penerima yang terletak di tangan operator berpotensi membuat kegagalan pengiriman pesan yang relatif besar, khususnya akibat kesalahan manusia (human error). Kesalahan ini meliputi kesalahan penulisan, seperti susunan kata atau kata-kata yang disingkat sehingga penerima bisa salah memahaminya. Nomor pager tujuan terkadang tidak ditulis dengan teliti yang berakibat pada terjadinya salah kirim. Masalah lain yang sering terjadi adalah kesalahan proses transliterasi dari pesan suara yang didengar operator menjadi pesan teks. Akibatnya, pesan teks akan mengalami distorsi makna yang besar.

Selain pager, terdapat alat komunikasi yakni telepon yang menjadi atribut komunikasi yang mengatasi jarak antarkomunikan. Interaksi yang berlangsung bersifat realtime, yakni sama waktunya antara dua pihak yang berkomunikasi. Pada telepon kabel, pertukaran pesan terjadi ketika suara merambat melalui kabel sambungan telepon analog. Selain salah sambung yang kerap terjadi karena nomor analog sering kurang akurat, kelemahan telepon kabel terletak pada ketidakpraktisannya. Kedua orang yang berkomunikasi harus langsung mengakses pesawat telepon dengan posisi tetap, tidak dapat berpindah sehingga sulit melakukan pembicaraan yang bersifat pribadi atau rahasia. Apalagi jika pesawat telepon tersebut berada di ruang publik, komunikasi melalui telepon kabel bisa menjadi gagal jika orang yang dituju tidak berada di tempat. Oleh karena itu, telepon kabel menjadi perangkat yang diandalkan untuk komunikasi jarak jauh, kedua belah pihak sering membuat janji atau bersepakat menentukan waktunya.

Kerepotan yang sempat muncul karena terbatasnya mobilitas pengguna telepon kabel telah menjadi tantangan tersendiri bagi para ahli yang bergerak di industri komunikasi untuk menghadirkan alat yang dapat menyampaikan pesan, walaupun orang yang dituju tidak berada di rumah atau tempat bekerja. Selain itu, otoritas pengguna menjadi semakin penting dan menjadi kelebihan tersendiri dalam perkembangan teknologi komunikasi. Istilah user friendly digunakan sebagai parameter kenyamanan bagi pengguna. Kendali terhadap siapa saja yang bisa menghubungi pengguna tampil dalam fitur reject untuk menolak atau block untuk menghalangi nomor tertentu melakukan kontak. Sebelumnya otoritas seperti itu belum pernah tersedia.

Kehadiran telepon genggam, yang populer disebut handphone atau telepon seluler karena nirkabel, membawa perubahan besar dalam metode komunikasi antarmanusia. Keberadaan telepon genggam yang berorientasi kepada kepentingan pengguna menjadi gerbang menuju revolusi industri ke-4. 
Handep, Vol. 2, No. 1, Desember 2018

Dengan dua bentuk informasi yang dikirimkan, yakni teks dan suara, telepon genggam semakin menjadi media komunikasi yang disukai. Teknologi komunikasi dalam genggaman terus menambahkan fiturfitur baru yang menjadikan telepon genggam tidak hanya sekadar alat komunikasi, melainkan juga teknologi yang membantu kehidupan manusia sehari-hari.

\section{Perkembangan Bahasa Dalam} Lirik Lagu Populer Indonesia yang Merekam Penggunaan Alat Komunikasi

Penggunaan teknologi komunikasi melahirkan bahasa komunikasi khusus yang pada awalnya hanya dipergunakan di kalangan para penggunanya, namun kemudian meluas hingga digunakan dalam percakapan sehari-hari. Fenomena adanya bahasa khusus ini dapat ditemukan pada lirik-lirik lagu pop Indonesia yang merekam penggunaan alat telekomunikasi.

Di kalangan para pengguna radio amatir atau HT, terdapat bahasa khusus berupa kode-kode, seperti yang ditunjukkan dalam lagu berjudul "Bercinta di Udara". Bahasa kode yang hanya digunakan dalam komunikasi antarpengguna tersebut, misalnya: "berQSQ yang merupakan kata sapaan (say hello); "cherio" sebagai salam perpisahan; "Papa Alpha Charlie Alpha Romeo" singkatan untuk kata "pacar"; serta Lima Oscar Victor Echo" singkatan dari kata "love".
Lirik lagu "Bercinta di Udara" yang dinyanyikan oleh Farid Hardja secara eksplisit menyebutkan bahwa terdapat interaksi sosial yang terjalin dengan menggunakan gelombang radio. Pada 1980an, kebiasaan berkomunkasi melalui radio amatir atau yang lebih populer dengan istilah "nge-break" menjadi salah satu tren hobi. Di saat itu, radio amatir boleh digunakan oleh masyarakat sipil di Indonesia. Tidak hanya para pelaku "nge-break", kode-kode yang berlaku dalam komunikasi melalui gelombang radio pun sering digunakan dalam percakapan keseharian di kalangan remaja masa itu untuk menunjukkan bahwa mereka paham kode alfabet, misalnya Alfa $=\mathrm{a}$, Bravo $=b$, Charlie $=C$, dan seterusnya . Selain itu terdapat istilah "roger" yang artinya baiklah, okey, atau dimengerti.

Lagu "Tujuh Kali Berdering” yang lekat dengan alat komunikasi berupa telepon, memopulerkan istilah atau kosakata "berdering", "salah sambung", dan "nomor". Kata "berdering" merujuk pada bunyi panggilan telepon rumah yang berbunyi sangat nyaring. Frasa "salah sambung" berkaitan dengan sambungan jaringan telepon rumah yang terhubung dengan kabel. Istilah "salah sambung" yang semula digunakan dalam komunikasi melalui telepon kabel hingga kini masih sering digunakan untuk menyatakan panggilan telepon yang menyasar pada tujuan yang tidak tepat, meskipun telepon kabel telah digantikan dengan telepon seluler. Sedangkan kata "nomor" yang awalnya menunjukkan semua urutan 
angka, dalam konteks alat komunikasi berupa telepon, kemudian dimaknai sebagai nomor kontak (nomor telepon) yang dapat dihubungi.

Di dalam lagu “Ti Di Dit”, terdapat lirik yang berbunyi: "Apa tuh pesan nyasar ke pager yang lain.”. Lagu ini telah mempopulerkan kata "pesan" yang diberi makna khusus, yakni dikaitkan dengan penggunaan alat komunikasi. Sebelum adanya pager, kata "pesan" belum dipahami sebagai tulisan yang dapat dibaca dari sebuah alat komunikasi elektronik. Sebagai perangkat penerima pesan tertulis bergerak (mobile) generasi pertama, keberadaan pager memang tidak sepopuler telepon seluler saat ini. Namun dengan adanya pager, kata "pesan" mulai memiliki makna khusus yang dipahami oleh para pengguna alat komunikasi sebagai tulisan yang dikirimkan dan dapat dibaca melalui fitur pesan pada alat komunikasi.

Kata "pesan" dengan makna khusus tersebut tetap bertahan di era penggunaan telepon seluler yang mengirimkan pesan melalui fitur SMS. Lirik lagu "I Miss You But I Hate You" yang berbunyi "Banyak pesan yang aku tinggalkan" memberikan gambaran tentang pesan berupa SMS yang terdapat telepon seluler. Fenomena tersebut menjelaskan adanya intertekstualitas kata "pesan" yang terdapat pada lagu "Ti Di Dit" dan "I Miss You But I Hate You". Keduanya memaknai kata "pesan" dengan pengertian yang sama, meskipun terdapat perbedaan pada perangkat komunikasi yang digunakan serta perbedaan dalam cara dan proses pengiriman pesan.

Kosakata baru yang dipopulerkan oleh lagu "I Miss You But I Hate You" adalah pulsa, seperti yang terdapat pada lirik "Banyak pulsa untuk menelepon kamu." Pulsa di sini berbeda artinya dengan kata pulse yang berarti denyut atau detak jantung dalam bahasa Inggris. Di Indonesia, pulsa dalam konteks alat telekomunikasi adalah sejumlah nominal tertentu dalam kartu SIM yang digunakan untuk membayar bea panggilan atau pengiriman SMS.

Di era komunikasi menggunakan internet, muncul kata chatting yang diperkenalkan melalui lagu "Malam Ini Ramli Chatting Lagi”. Kata chatting merupakan kosakata dalam bahasa Inggris yang memiliki arti mengobrol atau bercakap-cakap, yang pada awalnya dilakukan melalui pertemuan secara langsung (tatap muka) di antara orang-orang yang terlibat dalam percakapan tersebut. Dalam konteks teknologi komunikasi, chatting berpindah ke ruang-ruang di dunia maya (chat room). Selain chatting, di era internet muncul pula kata online yang dikenal luas melalui lagu berjudul sama milik Saikoji. Online diartikan sebagai status id (identitas) akun seseorang yang sedang aktif atau terkoneksi dengan jaringan internet.

Lagu "My Facebook" menjadi salah satu lagu yang turut mengangkat dan menyebarluaskan kata facebook sebagai aplikasi media sosial yang banyak digunakan oleh masyarakat 
Handep, Vol. 2, No. 1, Desember 2018

Indonesia hingga saat ini. Melalui facebook, para penggunanya dapat memasukkan identitas diri yang memungkinkan mereka untuk bertemu dengan pengguna atau komunitas lain yang memiliki kesamaan lokasi, karakter, minat, dan hal lainnya.

Penulis menemukan adanya beberapa kemiripan pada lirik-lirik lagu populer yang dikaji dalam penelitian ini. Kemiripan tersebut dihasilkan dari penempatan sudut pandang dan elemen penginderaan pribadi (self-censorhip) penulis lagu tersebut terhadap kondisi sosial masyarakat di suatu masa tertentu, khususnya yang berkaitan dengan penggunaan alat komunikasi dan bahasa khusus dalam berkomunikasi.

Analisis intertekstual merupakan kajian atas beberapa teks yang diduga memiliki bentuk-bentuk hubungan tertentu. Teks-teks yang dikaji dapat berasal dari satu periode yang sama maupun berbeda (Nurgiyantoro, 2000: 50). Menurut Pradopo (2007: 131), pada prinsipnya sebuah teks merupakan respon terhadap teks lainnya (Pradopo, 2007: 131). Hubungan antarteks ini dapat menunjukkan pertentangan, perbedaan atau persamaan di antara teks-teks yang dibandingkan tersebut.

Hasil analisis intertekstual atas teks-teks yang terdapat dalam lirik-lirik lagu populer yang merekam alat/ teknologi komunikasi dan penggunaan bahasa khusus dalam berkomunikasi menunjukkan adanya beberapa fakta yang dipaparkan berikut ini. Pertama, kemiripan situasi perkenalan seseorang dengan orang lain yang tidak terjadi melalui pertemuan langsung, melainkan diperantarai oleh media komunikasi. Pada lagu "Bercinta di Udara", bagian yang menceritakan proses berkenalan muncul pada lirik adalah sebagai berikut.

"Berkenalan nama samaran,

Lewat gelombang radio

5973 angka untuk kamu,

Ber QSO lalu cherio..."

(Sumber: https://youtu.be/

8c0kT1Yxoyc, diakses pada 13

Oktober 2018).

Dengan teknologi yang berbeda, perkenalan tak langsung juga ditemukan pada penggalan lirik lagu "Malam Ini Ramli Chatting Lagi”, yang berbunyi:

"Si Ramli raja chatting
punya gebeten namanya Putri
Bikin Ramli bilang wo ai ni emang
Ramli raja chatting
Terbayang wajah Putri
oleh Ramli di mato
Tak tahan Ramli cape cape
ingin basuo"

(Sumber: https://youtu.be/ c6tw3 UFvtuI, diakses pada13 Oktober 2018).

Lirik ini menceritakan Ramli yang berkenalan dengan Putri di dunia maya. Karena belum pernah bertemu secara langsung, ia hanya dapat membayangkan wajah Putri. Teknologi chatting di saat itu, baik mIRC maupun YM sudah dapat digunakan untuk mengirim foto atau video, meskipun kualitas gambarnya masih kurang baik. Tak tahan Ramli untuk segera berjumpa langsung dengan 
Putri karena perjumpaan sebelumnya hanya terjadi di dunia maya.

Beberapa komentar dari warganet terhadap lagu mIRC, diparodikan menjadi singkatan dari "Malam Ini Ramli Chatting" yang mewakili pengalaman berkenalan melalui media chatting dapat disimak di bawah ini.

Kiki Rizkianto (2017): "lagu lama 2003an ini, jaman jaman chating nanya asl pls hahaa."

Istilah "asl pls" adalah singkatan dari age, sex location dan please. Pada umumnya istilah tersebut adalah sapaan awal di saat memulai perkenalan saat chatting di chat room. Tujuannya adalah untuk menanyakan umur, jenis kelamin, dan lokasi lawan bicara.

Penggunaan platform lain untuk memfasilitasi perkenalan tanpa pertemuan langsung juga menjadi pengalaman warganet, sebagaimana komentar yang ditinggalkan pada kolom komentar di lagu "My Facebook" oleh GIGI yang dapat diakses di https://youtu.be/ o9TUjr04LZ8 berikut ini.

Praja Kirana (2017): “my facebook. kisah aku banget ni.. dpt kenalan cocok.. cantik.. and tangguh.. jalan.. nonton.. eh... g tau skarng knp dia menghindar.. ..padahal aku dah trlanjur suka.."

Didit Nugroho (2018): "Terima kasih dari facebook, $k u$ mendapatkan banyak kenalan wanita bahkan jadi pacar sekaligus pdkt dari facebook cuman 1 minggu langsung jadian....."
Kedua, kemiripan pada lirik-lirik lagu yang mengisahkan adanya komunikasi antara dua orang yang menjalin asmara secara tidak langsung. Komunikasi tersebut berlangsung melalui pemanfaatan teknologi komunikasi. Penggalan lirik yang menunjukkan situasi ini dapat ditemukan pada lagu "Bercinta di Udara", yaitu:

"Di udara aku menunggu

Kau panggil namaku

Kupanggil namamu

Papa Alpha Charlie Alpha Romeo

Mengajakku gombal di udara

Memang cinta asyik dimana saja

Walau di angkasa"

(Sumber: https://youtu.be/

8c0kT1Yxoyc, diakses pada 13

Oktober 2018).

Pemilihan judul "Bercinta di Udara" mengesankan penulis lagu memindahkan aktivitas bercinta (berpacaran) yang biasanya berlangsung di dunia nyata melalui pertemuan langsung ke dalam ruang baru, yakni melalui media gelombang radio atau "di udara". Di sini, komunikasi antarpengguna dapat terjalin melalui pertemuan di frekuensi gelombang yang sama tanpa diawali pertemuan dan perkenalan secara langsung. Penulis lirik lagu ini menangkap munculnya konsep "ruang” yang baru pada fenomena penggunaan HT, yaitu tempat orang-orang "bertemu" dan berinteraksi di luar dunia yang riil (nyata). Ruang baru ini dikonstruksi sesama pengguna HT tanpa didahului dengan tatap muka secara langsung dan 
Handep, Vol. 2, No. 1, Desember 2018

saling mengenal wajah sehingga membuka peluang bagi para pengguna alat komunikasi ini untuk menyamarkan identitas asli mereka.

Situasi yang mirip dengan penggalan lirik lagu "Bercinta di Udara" tesebut dijumpai pula pada lagu "Kugadaikan Cintaku", khususnya pada berikut ini.

“...Kutelepon di rumahmu, sedang apa Sayangku?

Kuharap engkau mendengar dan kukatakan rindu"

( S u mber: ht tp s: / / ww w . liriklaguindonesia.com/di-radiogombloh, diakses pada 13 Oktober 2018).

Ungkapan melalui kata-kata "sedang apa Sayangku", dan "kukatakan rindu" adalah percakapan yang terjadi antara dua orang dalam hubungan percintaan.

Perbedaan situasi pada lagu pertama dan kedua terdapat pada teknologi komunikasi yang digunakan. Lagu "Bercinta di Udara" menggunakan HT (radio amatir), sedangkan pada lagu "Kugadaikan Cintaku" menggunakan radio dan telepon kabel. Situasi yang menggambarkan hubungan percintaan yang terjadi di dunia maya dengan memanfaatkan teknologi komunikasi yang lebih baru, yakni SMS melalui telepon seluler, tergambar pada lirik lagu "I Miss You But I Hate You", yang berbunyi: "Berkali-kali aku SMS kamu, berkata mesra yang aku ucapkan."

Ketiga, kemiripan pada lirik-lirik lagu yang menggambarkan tentang gangguan yang disebabkan oleh bunyi alat komunikasi, yang memunculkan kekesalan, amarah, dan perasaan terusik karena bunyi tersebut merusak ketenangan. Suasana kacau dan rasa kesal yang terjadi karena menerima telepon yang ternyata salah sambung diungkapkan dalam lagu "Tujuh Kali Berdering" khususnya pada penggalan lirik berikut ini.

"Kau selalu bertanya

Nomor yang itu

Dan yang itu lagi

Aku pusing pening, tambah pening

Ini mungkin sinting"

(Sumber: https://youtu.be/

UYbztfwcLxA, diakses pada13

Oktober 2018).

Demikian pula pada lagu "Ti Di

Dit", gangguan yang disebabkan bunyi pager terekam dalam penggalan lirik seperti di bawah ini.

"Tidit pagernya berbunyi tidit tidit begitu bunyinya

Kadang punya pager bikin senang Kadang bikin resah, kadang bikin marah (2x)"

(Sumber: https://youtu.be/ qZ3pceoly80, diakses pada 13 Oktober 2018).

Kedua lagu di atas menunjukkan situasi perasaan yang muncul karena gangguan dari bunyi alat komunikasi yang digunakan. Lagu pertama mengisahkan gangguan yang disebabkan bunyi telepon, sedangkan lagu kedua bunyi pager. 


\section{PENUTUP}

Penggunaan alat komunikasi yang terekam dalam lirik-lirik lagu pop Indonesia dapat menggambarkan perkembangan teknologi komunikasi yang terjadi di Indonesia. Alat dan media komunikasi yang terdapat dalam lirik lagu tersebut adalah radio amatir, telepon kabel, radio, pager, telepon seluler dengan fitur SMS, jaringan internet, media sosial, dan gadget.

Sedangkan perkembangan bahasa yang terekam dalam lirik lagu populer sebagai implikasi dari penggunaan alat dan media komunikasi ditunjukkan melalui kemunculan kode-kode, istilah, dan kosakata baru yang digunakan sebagai bahasa komunikasi khusus di antara para penggunanya. Contoh, berQSQ, salah sambung, pulsa, online, dan chatting. Ada pula kata-kata yang mengalami perubahan makna ketika penggunaannya dikaitkan dengan alat komunikasi, seperti kata nomor dan pesan.

Analisis intertekstual atas teks-teks yang terdapat dalam lirik-lirik lagu populer tersebut menunjukkan adanya kemiripan antarteks dan situasi yang digambarkan. Pertama, perkenalan seseorang dengan orang lain tidak terjadi melalui pertemuan langsung melainkan menggunakan alat dan media komunikasi sebagai perantaranya. Kedua, hubungan percintaan terjalin secara tidak langsung, yakni menggunakan teknologi komunikasi. Ketiga, adanya gangguan yang disebabkan oleh bunyi alat komunikasi. Gangguan ini menimbulkan perasaan kesal, marah dan terusiknya ketenangan.

Komunikasi secara tidak langsung sering menimbulkan permasalahan karena adanya kelemahan/keterbatasan pada teknologi dan media komunikasi yang digunakan. Alat komunikasi tidak hanya bermakna sebagai alat bantu yang memudahkan para penggunanya untuk berkomunikasi, namun juga dapat dijadikan sebagai simbol status sosial bagi pemiliknya.

Produk budaya populer, seperti lagu dapat digunakan sebagai sarana penyimpan ingatan kolektif tentang fenomena sosial yang sedang menarik perhatian di suatu masa karena lagulagu populer relatif mudah diakses dan memiliki jangkauan yang luas.

\section{DAFTAR SUMBER}

Ahimsa-Putra, H.S. 2012. Budaya Bangsa: Peran untuk Jati Diri dan Integrasi. Makalah pada Seminar Nasional Peran Sejarah dan Budaya dalam Pembinaan Jatidiri Bangsa. Yogyakarta: Fakultas Ilmu Sosial Universits Negeri Yogyakarta.

Bayuardi, Galuh, Andang Firmansyah, Superman. 2017. Javanese Migran's World View In Olak-olak Kubu Village, District Kubu Raya, diunduh dari http://fis.unnes.ac.id/ v3/wp-content/uploads/2017/10/ 1.compressed-1-1.pdf, pada September 2018. 
Handep, Vol. 2, No. 1, Desember 2018

Bayuardi, Galuh, Dian Equanti, Egi Pratama Rizki. 2018. Evolusi Sistem Bahasa dan Teknologi Komunikasi, Ruang Virtual. Santoso, Edy (ed). Komunikasi Kontemporer: Dinamika Budaya, Jurnalisme, dan Kehumasan. Semarang: FISIP Universitas Jenderal Soedirman bekerja sama dengan Yayasan Literasi Bangsa, hlm. 115-124.

Behl, Ramesh. 2009. Information Technology for Management. London: Tata Mc. Grow-Hill Education

Bromley, K.D. 1992. Language Arts: Exploring Connection (2nd ed). Boston: Allyn and Bacon.

Equanti, D., Bayuardi, B. 2016. Konsep Kerabat di Daerah Rantau Bagi Mahasiswa Migran Pontianak. Sosial Horizon: Jurnal Pendidikan Sosial. Vol. 3, No. 1, Juni 2016, hlm. 14-28.

Faruk. 1988. Strukturalisme Genetik dan Epistimologi Sastra. Yogyakarta: Pustaka Pelajar.

Fiske, J. 2004. Cultural and Communication Studies: Sebuah Pengantar Paling Komprehensif. Terjemahan Yosal Iriantara dan Idi Subandi Ibrahim. Yogyakarta: Jalasutra.

Gans, Herbert J. 1974. Popular Culture and High Culture: An Analysis and
Evaluation of Taste. New York:

Basic Books, Inc., Publishers.

Grene, Doyle. 2014. The Rock Cover Song: Culture, History, Politics. Jefferson: McFarland \& Company, Inc.

https://youtu.be/8c0kT1Yxoyc, diakses pada 13 Oktober 2018.

https://youtu.be/43CRxT1OoDU, diakses pada 13 Oktober 2018.

https://youtu.be/d-GCrGTNvB0, diakses pada 13 Oktober 2018.

https://youtu.be/c6tw3UFvtuI, diakses pada 13 Oktober 2018.

https://youtu.be/o9TUjr04LZ8, diakses pada 13 Oktober 2018.

https://youtu.be/XEYkMaxZmIE, diakses pada 13 Oktober 2018.

https://youtu.be/qZ3pceoIy80, diakses pada 13 Oktober 2018.

https://youtu.be/UYbztfwcLxA, diakses pada 13 Oktober 2018.

https://www.youtube.com/watch?v=t5SJmw3LYI, diakses pada 13 Oktober 2018.

http://Musiklib.org/farid_hardjabercinta_di_udara-lirik_lagu.htm, diakses pada 13 Oktober 2018.

Hymes, D. 1964. Language in Culture and Society: A Reader in 
Linguistics and Anthropology. New York: Harper and Row.

Junaedi, D. 2016. Estetika: Jalinan Subjek, Objek, dan Nilai. Yogyakarta: Art for Civilization.

Kamus. Oxford Learner's Pocket Dictionary, Fourth Edition, 2008. Oxford University Press.

Koentjaraningrat. 2002. Pengantar Antropologi. Jakarta: Rineka Cipta.

Krueger, Robert F. 2012. Personality and Psychology. New York: Guild Press.

Kurniawan. 2001. Semiologi Roland Barthes. Magelang: Indonesiatera

Mayer, Richard E. 2009. Multimedia Learning: Prinsip-prinsip dan Aplikasi. Yogyakarta: Pustaka Pelajar.

Miller, D. 2016. How the World Changed Social Media. London: UCL Press.

Neuman, L. W. 2014. Basic of Social Research Method: Qualitative and Quantitative. Yogyakarta: Resda Karya.

Nurgiyantoro, Burhan. 2000. Teori Pengkajian Fiksi. Yogyakarta: Gadjah Mada University Press.
Pradopo, Rachmat Joko. 2007. Pengkajian Puisi. Yogyakarta: Gadjah Mada University Press.

Rogers, E. M. 1986. Communication Technology. New York: The Free Press.

Shaik, Fazlur Rehman. 2001. Chronology of Prophetic Events. London: Ta-Ha Publisher.

Shurmer-Smith, Pamela. 2002. Doing Cultural Geography. London: Sage Publication Ltd.

Silalahi, Patricia. 2015. Pemaknaan Lirik Lagu Judas (Studi Analisis Semiotika Lirik Lagu Lady Gaga yang berjudul Judas), diunduh dari http://jurnal.usu.ac.id/index.php/ flow/article/view/11615/4988, pada 20 November 2018 .

Soekanto, S. 1990. Sosiologi Suatu Pengantar. Jakarta: Raja Grafindo.

Spradley, J. P. 1972. Culture and Cognition: Rules, Maps, and Plans. Toronto: Chandler Publishing. 
